\title{
The mantle of Scotland viewed through the Glen Gollaidh aillikite
}

\author{
M. T. Hutchison ${ }^{1}$, J. W. Hughes ${ }^{2}$, J. W. Faithfull ${ }^{3}$ \\ ${ }^{1}$ Trigon GeoServices Ltd., Las Vegas, NV, USA, mth@trigon-gs.com \\ ${ }^{2}$ Department of Earth Sciences, University of Durham,Durham,UK, joshua.w.hughes@durham.ac.uk \\ ${ }^{3}$ Hunterian Museum, University of Glasgow, Glasgow, UK, John.Faithfull@glasgow.ac.uk
}

\section{Introduction}

Smith et al. (2008) and Faithfull (2012) describe a carbonate-rich olivine macrocrystal dyke in Sutherland, Scotland. The $1 \mathrm{~m}$ wide dyke, named after its location in Glen Gollaidh, outcrops at $58.3675^{\circ} \mathrm{N} 4.6975^{\circ} \mathrm{W}$, to the west of Ben Hope. Stream-bed outcrops can be seen at two further locations $<75 \mathrm{~m}$ west northwest along the Allt Strath Feinne-Bheinn and a fourth lies $250 \mathrm{~m}$ east southeast along the ca. $100^{\circ}$ strike (Hughes, 2012).

Primary minerals consist of olivine (fresh and serpentinised), calcite, phlogopite (tetraferriphlogopite rims), clinopyroxene (cpx), apatite, chromite, magnetite, and accessory perovskite, rutile, $\mathrm{Ca}-\mathrm{Ti}-(\mathrm{REE})$ and $\mathrm{Zr}$ oxides. The presence of primary cpx precludes identification as kimberlite. However, mineralogy and bulk chemistry (Hughes, 2012) are consistent with a classification as aillikite (after Tappe et al. 2005). Mineralogy is variable with parts of the dyke transitioning to carbonatite ( $>50 \%$ carbonate), in a similar fashion to aillikite / carbonatite associations in West Greenland (Hutchison and Frei, 2009). Larger olivines and orthopyroxene (opx) xenocrysts and abundant serpentinised spinel lherzolite xenoliths $(\leq 3 \mathrm{~cm})$ reflect a mantle component. Weathered surfaces show the very competent, sandpaper textured orange-brown knobbly appearance ubiquitous in North Atlantic Craton (NAC) aillikites (Hutchison and Frei, 2009).

\section{Age determination}

Five batches of groundmass phlogopite separates were dated at the SUERC Argon Isotope Facility, East Kilbride, UK. ${ }^{40} \mathrm{Ar} /{ }^{39} \mathrm{Ar}$ geochronology gives a late Devonian emplacement age of $363 \mathrm{Ma}( \pm 2 \mathrm{Ma} 2 \sigma$; MSWD 1.63, $\mathrm{n}=17)$. Caledonian metamorphism associated with the Moine Thrust largely ceased at $429 \mathrm{Ma}$ (Goodenough et al. 2011) although some minor alkali intrusives and fenitised rocks along the Great Glen are as young as ca. $390 \mathrm{Ma}$ (Macdonald and Fettes, 2007). The Glen Gollaidh emplacement age is ca. $50 \mathrm{Ma}$ after the final closure of the Iapetus and pre-dates the intra-plate alkali magmatism that affected southern Scotland from ca. $350 \mathrm{Ma}$. Aillikites have not otherwise been recorded in the UK and with an age determination, the Glen Gollaidh dyke provides an opportunity to study the mantle component of the Scottish part of the NAC in the specific context of the late Devonian.

\section{Mantle mineralogy}

A single $9.8 \mathrm{~kg}$ sample was disaggregated to $<1 \mathrm{~mm}$ in two batches by high-voltage pulse fragmentation (SelFrag AS) with all fines retained. All $6.05 \mathrm{~kg}$ of $0.25-1.0 \mathrm{~mm}$ grains, and $500 \mathrm{~g}$ of $0.18-0.25 \mathrm{~mm}$ were liquid density separated (S.G. 2.96; SRC, Saskatchewan) with a purpose-designed flowsheet built to retain any microdiamonds. After mineral picking, $38 \mathrm{~g}$ of sample was archived and the total remaining sample was treated by caustic fusion. While all fifteen quality-control tracer diamonds were recovered, the aillikite was found to be barren of diamond to the minimum size of $0.075 \mathrm{~mm}$ tested. Inspection of heavy mineral concentrates recovered abundant chromites, Cr-diopsides (in both size fractions) and four olivine grains $(>0.25 \mathrm{~mm})$. No perovskite, picro-ilmenite or garnet was identified.

Major element chemistry was determined by Cameca SX100 electron microprobe ( $15 \mathrm{keV}, 10$ and 100 nA; Univ. Edinburgh) with minerals classified following references in Hutchison and Frei (2009). The large majority of picked spinels are $\mathrm{Mg}, \mathrm{Al}$ chromites with compositions coinciding with chromites in kimberlites, within the garnet peridotite field (based on Ti and Cr content; Grütter and Apter, 1998) and describing the spinel Trend 2 based on divalent / trivalent cations. Cr content $\left(<47.2 \% \mathrm{Cr}_{2} \mathrm{O}_{3}\right)$ is not 
high enough to be consistent with the diamond stability field. Cpx compositions range from 2.6-6.6 $\mathrm{wt} \% \mathrm{Al}_{2} \mathrm{O}_{3}$ and 19.9-23.9 $\mathrm{wt} \% \mathrm{CaO}$ encompassing, at one place, most of the 'remarkable range' (Upton et al. 2011) exhibited by Scottish mantle-derived cpx compared to world-wide xenolith localities. Based on $\mathrm{Cr}$ and $\mathrm{Al}$ content, the majority of $\mathrm{Cr}$-diopsides are consistent with spinel lherzolite compositions (CLS) although a significant proportion (30\%) also plot in the garnet peridotite (CGP) field with $\mathrm{Cr}_{2} \mathrm{O}_{3}$ content up to $1.56 \%$. Olivines are $\mathrm{Mg}$-rich $\left(\mathrm{Fo}_{89}-\mathrm{Fo}_{91}\right.$ ) and, with $\mathrm{Ni}$ contents (confirmed by trace element measurements) in excess of $3000 \mathrm{ppm}$, are more similar to those from Type Ia kimberlites than aillikites found elsewhere in the North Atlantic Craton, in West Greenland (Hutchison and Frei, 2009).

Concentrations for 27 trace elements were determined by laser ablation inductively coupled plasmamass spectrometry (ICP-MS; 47-137 $\mu \mathrm{m}, 5$ and $10 \mathrm{~Hz}$; ANU, Canberra). Cr-diopsides express four distinct rare-earth element (REE) trends. Of 41 grains, the most common trend (63\%) shows a LREE enrichment up to 50x chondrite, to chondritic values amongst the HREE. Trends are similar to those from Rinibar cpx (north of Glen Gollaidh; Upton et al. 2011). A further 22\% of grains show the opposite trend: La and $\mathrm{Ce}$ are slightly enriched (some with Ce enriched over La relative to chondrite), $\mathrm{Nd}$ and Sm have chondriditic values and HREE are up to $10 \mathrm{x}$ chondrite. Five grains $(12 \%)$ show a flat REE trend consistently close to 10x chondritic and similar to trends from Streap Com'Laidh and Fidra cpx (south of Glen Gollaidh; Upton et al. 2011). A single outlier shows a sinuous trend, LREE enriched and with a minimum at Dy $(0.49 \mathrm{ppm})$ resembling the average Rinibar samples of Hughes et al. (2015).

\section{Mantle conditions}

The Glen Gollaidh dyke is hosted within the Neoproterozoic sedimentary rocks of the Moine Supergroup. However, it occurs ca. $4 \mathrm{~km}$ east of the Moine Thrust, marking the westernmost extent of the Caledonian metamorphism in Britain. Mantle mineralogy and the proximity to the Moine Thrust leads to the conclusion that the dyke overlies buried Lewisian sub-continental lithospheric mantle, the crustal counterpart of which dominates outcrops in Scotland lying to the west of the Moine Thrust. The Lewisian comprises a part of the reworked North Atlantic Craton (NAC) mobile belt, most of which is preserved to the north west in the previously adjoining Greenlandic component, there termed the Nagssugtoqidian Orogen. The Glen Gollaidh dyke lies almost exactly half way between Loch Roag and Rinibar mantle peridotite suites, both of which are concluded by Hughes et al. (2015) to evidence an underlying keel of NAC which is not present ca. $175 \mathrm{~km}$ south at Streap Com'Laidh.

The absence of garnet, relatively low Cr-content chromite and spinel lherzolite Cr-diopside compositions are consistent with the failure of the small sample tested to yield diamonds. The cratonic root underlying the Glen Gollaidh aillikite during the late Devonian was apparently too thin to lie within the diamond stability field, consistent with xenoliths from alkali basalts elsewhere in Scotland (Upton et al. 2011). Examples of diamond-hosting rocks with spinel rather than garnet lherzolites are known (Archangelsk, Russia; Capita and Lehmann, 2000) but they are very rare. The small sample size tested for diamonds does not definitively prove that the body is non-diamondiferous but the negative result for both garnet and diamond makes the commercial prospects of the dyke itself very unlikely.

Despite the dominant affinities with spinel lherzolites, LREE-enriched clinopyroxene is consistent with crystallisation with garnet as are a significant portion of grains' major element compositions. Opx has been identified in lherzolite xenoliths but in the absence of opx chemistry, the opx-cpx solvus thermometer (Bertrand and Mercier, 1985) provides minimum temperature estimates. Cr-diopside compositions require at least $22 \mathrm{kbar}(65 \mathrm{~km})$ to give an average minimum temperature of $961^{\circ} \mathrm{C}$. Given the spread of data, this is the smallest pressure which results in cool enough temperatures for some cpx compositions to coincide with even a warm $\left(42 \mathrm{mWm}^{-2}\right)$ geotherm. More robust geothermobarometry is warranted. However, calculations place some mantle components from the dyke close to the spinelgarnet transition (although firmly within the graphite stability field) and consistent with the conclusions from independent mineral chemistry. Despite the absence of diamond, mineral chemistry potentially places the dyke as hosting some of the deepest mantle components recovered in the UK. The Glen 
Gollaidh aillikite apparently sat at the edge of diamond-prospective mantle suggesting diamond potential a short distance to the west within the Lewisian and also what is now East Greenland.

Isotopic and bulk rock trace element data suggest a highly enriched lithospheric source (Faithfull, 2012). On the Isle of Lewis, the Loch Roag monchiquite dyke (Menzies et al. 1989) has a similar enriched trace-element signature. High LREE enrichment can imply partial melting in equilibration with garnet. Alternatively, the apparent absence of garnet supports small degrees of melting of shallower, previously metasomatised mantle, favoured by Upton et al. (2011). It is apparent from other studies (e.g. Upton et al. 2011; Hughes et al, 2015) that the Scottish mantle has experienced an unusually complex history of fragmentation, amalgamation and sporadic metasomatism. This conclusion is very much borne out at Glen Gollaidh, particularly in the considerable variability in spinel and clinopyroxene compositions. Likely the variability reflects a large depth range sampled within the mantle contributing to the Glen Gollaidh aillikite, and its late Devonian age after the conclusion of the upheavals associated with the closure of the Iapetus and accumulation of Laurussia (Macdonald and Fettes, 2007).

Study of the Glen Gollaidh aillikite provides closer understanding of the limits of diamond prospective areas at the peripheries of the NAC, likely a relatively short distance to the north and west. Furthermore, the considerable variability of mantle geochemistry at Glen Gollaidh represents a microcosm of North Atlantic Craton evolution supporting a complex multi-component evolution and justifying further work.

Acknowledgements Brian Upton (Univ. Edinburgh; guidance), Dan Barfod (SUERC; geochron.), Chris Hayward (Univ. Edinburgh; electron probe), Hugh O’Neill, Greg Yaxley, Jung-Woo Park (ANU; ICP support), Wayne Taylor (ICP standards), Alex Weh (SelFrag), Cristiana Mirceau (SRC; sample processing), and Heather Gow (site access) are gratefully acknowledged.

\section{References}

Bertrand P, Mercier J-CC (1985) The mutual solubility of coexisting ortho- and clinopyroxene: toward an absolute geothermometer for the natural system? Earth Planet Sci Lett 76:109-122

Capita AA, Lehmann B (2000) The new Archangelsk diamond province, NW Russia. Erzmetall 53:357-363

Faithfull JW (2012) Gem sapphire and diamond potential in NW Scotland. Trans Inst Min Met B 120:64

Goodenough KM, Millar I, Strachan RA, Krabbendam M, Evans JA (2011) Timing of regional deformation and development of the Moine Thrust Zone in the Scottish Caledonides: constraints from U-Pb geochronology of alkaline intrusions. J Geol Soc London 168:99-144

Grütter HS, Apter DB (1998) Kimberlite- and lamproite-borne chromite phenocrysts with "diamond inclusion"-type chemistries. 7th Int Kimb Conf Ext Abstr, pp 280-282

Hughes HSR, McDonald I, Faithfull JW, Upton BGJ, Downes H (2015) Trace-element abundances in the shallow lithospheric mantle of the North Atlantic Craton margin: Implications for melting and metasomatism beneath Northern Scotland. Mineral Mag 79:877-907

Hughes JW (2012) The First Reported Occurrence of Aillikite from the United Kingdom: Potential for the GLSDP? MESci thesis, Cardiff University

Hutchison MT, Frei D (2009) Kimberlite and related rocks from Garnet Lake, West Greenland, including their mantle constituents, diamond occurrence, age and provenance. Lithos 112S:318-333

Macdonald R and Fettes DJ (2007) The tectonomagmatic evolution of Scotland. Trans Royal Soc Edinburgh: Earth Sci 97:213-295

Menzies MA, Halliday AN, Hunter RH, MacIntyre RM, Upton BJG (1989) The age, composition and significance of a xenolith-bearing monchiquite dike, Lewis, Scotland. Geol Soc Australia Spec Publ. 14:843-852

Smith CG, Faithfull JW, Jackson B (2008) Gemstone prospectivity in Scotland. In: Walton G (ed) The proceedings of the 14th Extractive Industry Conference. EIG Conferences, pp 9-11

Tappe S, Foley SF, Jenner GA, Kjarsgaard BA (2005) Integrating ultramafic lamprophyres into the IUGS Classification of Igneous Rocks: Rationale and implications. J Petrol 46:1893-1900

Upton BGJ, Downes H, Kirstein LA, Bonadiman C, Hill PG, Ntaflos T (2011) The lithospheric mantle and lower crust-mantle relationships under Scotland: a xenolithic perspective. J Geol Soc London 168:873-885 